\title{
Climate change: impacts on fisheries and aquaculture
}

\author{
Bimal P Mohanty ${ }^{1}$, Sasmita Mohanty², \\ Jyanendra K Sahoo ${ }^{3}$ and Anil P Sharma ${ }^{1}$ \\ ${ }^{1}$ Central Inland Fisheries Research Institute, Barrackpore, Kolkata 700120; \\ ${ }^{2}$ School of Biotechnology, KIIT University, Bhubaneswar 751024, \\ ${ }^{3}$ Orissa University of Agriculture \& Technology, College of Fisheries, Berhampur760007;
}

India.

Climate change has been recognized as the foremost environmental problem of the twentyfirst century and has been a subject of considerable debate and controversy. It is predicted to lead to adverse, irreversible impacts on the earth and the ecosystem as a whole. Although it is difficult to connect specific weather events to climate change, increases in global temperature has been predicted to cause broader changes, including glacial retreat, arctic shrinkage and worldwide sea level rise. Climate change has been implicated in mass mortalities of several aquatic species including plants, fish, corals and mammals. The present chapter has been divided in to two parts; the first part discusses the causes and general concerns of global climate change and the second part deals, specifically, on the impacts of climate change on fisheries and aquaculture, possible mitigation options and development of suitable monitoring tools.

\section{Global Climate change: Causes and concerns}

Climate change is the variation in the earth's global climate or in regional climates over time and it involves changes in the variability or average state of the atmosphere over durations ranging from decades to millions of years. The United Nations Framework Convention on Climate Change (UNFCCC) uses the term 'climate change' for human-caused change and 'climate variability' for other changes. In last 100 years, ending in 2005, the average global air temperature near the earth's surface has been estimated to increase at the rate of $0.74+/$ $0.18{ }^{\circ} \mathrm{C}\left(1.33+/-0.32{ }^{\circ} \mathrm{F}\right)$ (IPCC 2007). In recent usage, especially in the context of environmental policy, the term 'climate change' often refers to changes in the modern climate.

\section{Causes of climate change}

There are both natural processes and anthropogenic activities affecting the earth's temperature and the resultant climate change. The steep increases in the global 
anthropogenic greenhouse gas (GHG) emissions over the decades are major contributors to the global warming.

\subsection{Natural processes affecting the earth's temperature}

Sun is the primary source of energy on earth. Though the sun's output is nearly constant, small changes over an extended period of time can lead to climate change. The earth's climate changes are in response to many natural processes like orbital forcing (variations in its orbit around the Sun), volcanic eruptions, and atmospheric greenhouse gas concentrations. Changes in atmospheric concentrations of greenhouse gases and aerosols, land-cover and solar radiation alter the energy balance of the climate system and causes warming or cooling of the earth's atmosphere. Volcanic eruptions emit many gases and one of the most important of these is sulfur dioxide $\left(\mathrm{SO}_{2}\right)$ which forms sulfate aerosol $\left(\mathrm{SO}_{4}\right)$ in the atmosphere.

\subsection{Greenhouse gases}

Greenhouse gases (GHGs) are those gaseous constituents of the atmosphere, both natural and anthropogenic, that are responsible for the greenhouse effect, leading to an increase in the amount of infrared or thermal radiation near the surface. While water vapor $\left(\mathrm{H}_{2} \mathrm{O}\right)$, carbon dioxide $\left(\mathrm{CO}_{2}\right)$, nitrous oxide $\left(\mathrm{N}_{2} \mathrm{O}\right)$, methane $\left(\mathrm{CH}_{4}\right)$, and ozone $\left(\mathrm{O}_{3}\right)$ are the primary greenhouse gases in the Earth's atmosphere, there are a number of entirely human-made greenhouse gases in the atmosphere, such as the halocarbons and other chlorine- and bromine-containing substances. Halocarbons such as CFCs (chlorofluorocarbons) are completely artificial (man-made), and are produced from the chemical industry in which they are used as coolants and in foam blowing.

Increases in $\mathrm{CO}_{2}$ are the single largest factor contributing more than $60 \%$ of humanenhanced increases and more than $90 \%$ of rapid increase in past decade. Most $\mathrm{CO}_{2}$ emissions are from the burning of fossil fuels such as coal, oil, and gas. Rising $\mathrm{CO}_{2}$ is also related to deforestation, which eliminates an important carbon sink of the terrestrial biosphere (www.ncdc.noaa.gov/oa/climate/globalwarming.html; Shea et al., 2007). Currently, the atmosphere contains about $370 \mathrm{ppm}$ of $\mathrm{CO}_{2}$, which is the highest concentration in 420000 years and perhaps as long as 2 million years. Estimates of $\mathrm{CO}_{2}$ concentrations at the end of the $21^{\text {st }}$ century range from 490 to $1260 \mathrm{ppm}$, or a $75 \%$ to $350 \%$ increase above preindustrial concentrations (WMO World Data Centre for Greenhouse Gases. Greenhouse gas bulletin, 2006; Shea KM and the Committee on Environmental Health, 2007).

\section{Impacts of climate change}

Although it is difficult to connect specific weather events to global warming, an increase in global temperatures may in turn cause broader changes, including glacial retreat, arctic shrinkage, and worldwide sea level rise. Changes in the amount and pattern of precipitation may result in flooding and drought. Other effects may include changes in agricultural yields, addition of new trade routes, reduced summer stream flows, species extinctions, and increases in the range of disease vectors (Understanding and responding to Climate Change. 2008: http://www.national-academies.org). 
Most models on Global climate change indicate that snow pack is likely to decline on many mountain ranges in the west, which would bring adverse impact on fish populations, hydropower, water recreation and water availability for agricultural, industrial and residential use. Partial loss of ice sheets on polar land could imply meters of sea level rise, major changes in coastlines and inundation of low-lying areas, with greatest effects in river deltas and low-lying islands. Such changes are projected to occur over millennial time scales, but more rapid sea level rise on century time scales cannot be excluded. Current models of climate change predict a rise in sea surface temperatures of between $2{ }^{\circ} \mathrm{C}$ and $5{ }^{\circ} \mathrm{C}$ by the year 2100 (IPCC Third Assessment Report, 2001: Done et al., 2003).

Climate change will affect ecosystems and human systems like agricultural, transportation and health infrastructure. The regions that will be most severely affected are often the regions that are the least able to adept. Bangladesh is projected to lose $17.5 \%$ of its land if sea level rises about 1 meter (39 inches), displacing millions of people. Several islands in the South Pacific and Indian oceans may disappear. Many other coastal regions will be at increased risk of flooding, especially during storm surges, threatening animals, plants and human infrastructure such as roads, bridges and water supplies.

There are many ways in which climate change might affect human health, including heat stress, heat (sun) stroke, increased air pollution, and food scarcities due to drought and other agricultural stresses. Because many disease pathogens and carriers are strongly influenced by temperature, humidity and other climate variables, climate change may also influence the spread of infectious diseases or the intensity of disease outbreaks. During the last 100 years, anthropogenic activities related to burning fossil fuel, deforestation and agriculture has led to a $35 \%$ increase in the $\mathrm{CO}_{2}$ levels in the temperature and this has resulted in increased trapping of heat and the resultant increase in the earth's atmosphere. Most of the observed increase in globally-averaged temperatures has been attributed to the greenhouse gas concentrations. The globally averaged surface temperature rise has been projected to be $1.1-6.4^{\circ} \mathrm{C}$ by end of the $21^{\text {st }}$ century (2090-2099) which is mainly due to thermal expansion of the ocean (www.searo.who.int/en/Section260/Section2468_ 14335.htm, 2008). The global average sea level rose at an average rate of $1.8 \mathrm{~mm}$ per year from 1961 to 2003 and the total rise during the $20^{\text {th }}$ century was estimated to be $0.17 \mathrm{~m}$ (The Fourth Assessment Report of IPCC, 2007). Due to such surface warming it is predicted that heat waves and heavy precipitations will continue to become more frequent with more intense and devastating tropical cyclones (typhoons and hurricanes). Due to the resultant disruption in ecosystem's services to support human health and livelihood, there will be strong negative impact on the health system. IPCC has projected an increase in malnutrition and consequent disorders, with implications for child growth and development. Increased burden of diarrheal diseases and infectious disease vectors are expected due to the erratic rainfall patterns.

Climate change is likely to lead to some irreversible impacts. Approximately $20-30 \%$ of species assessed so far are likely to be at increased risk of extinction if increases in global average warming exceed $1.5-2.5^{\circ} \mathrm{C}$ (relative to 1980-1999). As global average temperature increase exceeds about $3.5^{\circ} \mathrm{C}$, model projections suggest significant extinctions $(40-70 \%$ of species assessed) around the globe. Some projected regional impacts of Climate change have been systematically listed in the IPCC Fourth Assessment Report, 2007. 


\section{Impacts of Climate Change on Fisheries and Aquaculture}

Fish has been an important part of the human diet in almost all countries of the world. It is highly nutritious; it can provide vital nutrients absent in typical starchy staples which dominate poor people's diets (FAO, 2005a; FAO, 2007a). Fish provides about $20 \%$ of animal protein intake (Thorpe et al., 2006) and is one of the cheapest sources of animal proteins as far as availability and affordability is concerned. While it serves as a health food for the affluent world owing to the fish oils rich in polyunsaturated fatty acids (PUFAs), for the people in the other extreme of the nutrition scale, fish is a health food owing to its proteins, oils, vitamins and minerals and the benefits associated with the consumption of small indigenous fishes (Mohanty et al., 2010a).

Although aquaculture has been contributing an increasingly significant proportion of fish over recent decades, approximately two-thirds of fish are still caught in capture fisheries. The number of people directly employed in fisheries and aquaculture is estimated at 43.5 million, of which over $90 \%$ are small -scale fishers (FAO, 2005a). In addition to those directly employed in fishing, over 200 million people are thought to be dependent on smallscale fishing in developing countries, in terms of other economic activities generated by the supply of fish (trade, processing, transport, retail, etc.) and supporting activities (boat building, net making, engine manufacture and repair, supply of services to fisherman and fuel to fishing boats etc.) in addition to millions for whom fisheries provide a supplemental income (FAO, 2005a). Fisheries are often available in remote and rural areas where other economic activities are limited and can thus be important sources for economic growth and livelihoods in rural areas with few other economic activities (FAO, 2005a)

\subsection{Potential impacts of climate change on fisheries}

Climate change is projected to impact broadly across ecosystems, societies and economics, increasing pressure on all livelihoods and food supplies. The major chunk of earth is encompassed by water that harbors vast majority of marine and freshwater fishery resources and thus likely to be affected to a greater extent by vagaries of climate change. Capture fisheries has unique features of natural resource harvesting linked with global ecosystem processes and thus is more prone to such problems. Aquaculture complements and increasingly adds to the supply chain and has important links with capture fisheries and is likely to be affected when the capture fisheries is affected.

The ecological systems which support fisheries are already known to be sensitive to climate variability. For example, in 2007, the International Panel on Climate Change (IPCC) highlighted various risks to aquatic systems from climate change, including loss of coastal wetlands, coral bleaching and changes in the distribution and timing of fresh water flows, and acknowledged the uncertain effect of acidification of oceanic water which is predicted to have profound impacts on marine ecosystems (Orr et al., 2005). Similarly, fishing communities and related industries are concentrated in coastal or low lying zones which are increasingly at risk from sea level rise, extreme weather events and wide range of human pressures (Nicholls et al., 2007a). While poverty in fishing communities or other forms of marginalization reduces their ability to adapt and respond to change, increasingly globalized fish markets are creating new vulnerabilities to market disruptions which may result from climate change. 
Fisheries and fisher folk may have the impact in a wide range of ways due to climate change. The distribution or productivity of marine and fresh water fish stocks might be affected owing to the processes such as ocean acidification, habitat damage, changes in oceanography, disruption to precipitation and freshwater availability (Daw et al., 2009).

Climate change, in particular, rising temperatures, can have both direct and indirect effects on global fish production. With increased global temperature, the spatial distribution of fish stocks might change due to the migration of fishes from one region to another in search of suitable conditions. Climate change will have major consequences for population dynamics of marine biota via changes in transport processes that influence dispersals and recruitment (Barange and Perry, 2009). These impacts will differ in magnitude and direction for populations within individual marine species whose geographical ranges span large gradients in latitude and temperature, as experimented by Mantzouni and Mackenzie (2010) in cod recruitment throughout the north Atlantic. The effects of increasing temperature on marine and freshwater ecosystems are already evident, with rapid pole ward shifts in distributions of fish and plankton in regions such as North East Atlantic, where temperature change has been rapid (Brander, 2007). Climate change has been implicated in mass mortalities of many aquatic species, including plants, fish, corals, and mammals (Harvell et al., 1999; Battin et al., 2007).

Climate change will have impact on global biodiversity; alien species would expand into regions in which they previously could not survive and reproduce (Walther et al., 2009). Climate driven changes in species composition and abundance will alter species diversity and it is also likely to affect the ecosystems and the availability, accessibility, and quality of resources upon which human populations rely, both directly and indirectly through food web processes. Extreme weather events could result in escape of farmed stock and contribute to reduction in genetic diversity of wild stock affecting biodiversity.

Climate variability and change is projected to have significant effects on the physical, chemical, and biological components of northern Canadian marine, terrestrial, and freshwater systems. According to a study conducted by Prowse et al. (2009), the northward migration of species and the disruption and competition from invading species are already occurring and will continue to affect marine, terrestrial, and freshwater communities. This will have implications for the protection and management of wildlife, fish, and fisheries resources; protected areas; and forests. Shifting environmental conditions will likely introduce new animal-transmitted diseases and redistribute some existing diseases, affecting key economic resources and some human populations. Stress on populations of iconic wildlife species, such as the polar bear, ringed seals, and whales, will continue as a result of changes in critical sea-ice habitat interactions. Where these stresses affect economically and culturally important species, they will have significant effects on people and regional economies. Further integrated, field-based monitoring and research programs, and the development of predictive models are required to allow for more detailed and comprehensive projections of change to be made, and to inform the development and implementation of appropriate adaptation, wildlife, and habitat conservation and protection strategies.

Fisheries will also be exposed to a diverse range of direct and indirect climate impacts, including displacement and migration of human populations; impacts on coastal communities and infrastructure due to sea level rise; and changes in the frequency, distribution or intensity of tropical storms. Inland fisheries ecology is profoundly affected 
by changes in precipitation and run-off which may occur due to climate change. Lake fisheries in Southern Africa for example, will likely be heavily impacted by reduced lake levels and catches. The variety of different impact mechanisms, complex interactions between social, ecological and economic systems and the possibility of sudden and surprising changes make future effects of climate change on fisheries difficult to predict. In fact, understanding the ecological impacts of climate change is a crucial challenge of the twenty-first century. There is a clear lack of general rules regarding the impacts of global warming on biota. A study conducted by Daufresne et al. (2009) provided evidence that reduced body size is the third universal ecological response to global warming in aquatic systems besides the shift of species ranges toward higher altitudes and latitudes and the seasonal shifts in life cycle events.

Apart from fisheries, global primary production (planktonic primary production) which is related to global fisheries catches at the scale of Large Marine Ecosystems appears to be declining, in some part due to climate variability and change, with consequences for the near future fisheries catches (Chassot et al., 2010).

Other climatic change impacts on fisheries include surface winds, high $\mathrm{CO}_{2}$ levels and variability in precipitations. While surface wind would alter both the delivery of nutrients in to the photic zone and strength and distribution of ocean currents, higher $\mathrm{CO}_{2}$ levels can change the ocean acidity and variability in precipitation would affect sea levels. Global average sea level is rising at an average rate of $1.8 \mathrm{~mm}$ per year since 1961 and there is evidence of increased variability in sea level in recent decades. It is recently reported that ocean temperature and associated sea level increases between 1961 and 2003 were 50\% larger than estimated in the 2007 IPCC Report. All coastal ecosystems are vulnerable to sea level rise and more direct anthropogenic impacts. Sea level rise may reduce intertidal habitat areas in ecologically important regions thus affecting fish and fisheries.

\subsection{Impact of climate change on the parasites and infectious diseases of aquatic animals}

The potential trends of climate change on aquatic organisms and in turn in fisheries and aquaculture are less well documented and have primarily concentrated on coral bleaching and associated changes. An increase in the incidence of disease outbreaks in corals and marine mammals together with the incidence of new diseases has been reported. It was suggested that both the climate and human activities may have accelerated the global transport of species, bringing together of pathogens and previously unexposed populations (Harvell et al., 1999; De Silva and Sato, 2009).

Climate changes could affect productivity of aquaculture systems and increase the vulnerability of cultured fish to diseases. All aquatic ecosystems, including freshwater lakes and rivers, coastal estuarine habitats and marine waters, are influenced by climate change (Parry et al., 2007; Scavia et al., 2002; Schindler, 2001). Relatively small temperature changes alter fish metabolism and physiology, with consequences for growth, fecundity, feeding behavior, distribution, migration and abundance (Marcogliese, 2008). The general effects of increased temperature on parasites include, rapid growth and maturation, earlier onset of spring maturation, increased parasite mortality, increased number of generations per year, increased rates of parasitism and disease, earlier and prolonged transmission, the possibility of continuous, year-round transmission (Marcogliese, 2001). 
Many diseases display greater virulence at higher temperatures that might be the result of reduced resistance of the host due to stress or increased expression of virulence factors/ increased transmission of the vectors. Some examples have been summarized in table 1.

\begin{tabular}{|c|c|c|c|}
\hline Host & Disease /Parasite & $\begin{array}{l}\text { Response to high } \\
\text { temperature }\end{array}$ & Reference \\
\hline $\begin{array}{l}\text { Largemouth } \\
\text { bass } \\
\text { (Micropterus } \\
\text { salmoides) }\end{array}$ & $\begin{array}{l}\text { Red sore disease } \\
\text { /bacterium Aeromonas } \\
\text { hydrophila }\end{array}$ & $\begin{array}{l}\text { Susceptibility to the } \\
\text { disease increases }\end{array}$ & $\begin{array}{l}\text { Esch and } \\
\text { Hazen (1980) }\end{array}$ \\
\hline $\begin{array}{l}\text { Mosquitofish } \\
\text { (Gambusia } \\
\text { affinis) }\end{array}$ & $\begin{array}{l}\text { Asian fish tapeworm } \\
\text { (Bothriocephalus } \\
\text { acheilognathi) }\end{array}$ & -do- & $\begin{array}{l}\text { Granath and } \\
\text { Esch (1983) }\end{array}$ \\
\hline $\begin{array}{l}\text { Trout } \\
\text { (Onchorhynchus } \\
\text { spp.) }\end{array}$ & $\begin{array}{l}\text { Whirling disease / } \\
\text { Myxozoan Myxobolus } \\
\text { cerebralis }\end{array}$ & -do- & $\begin{array}{l}\text { Hiner and } \\
\text { Moffitt (2001) }\end{array}$ \\
\hline $\begin{array}{l}\text { Juvenile coho } \\
\text { salmon }(O . \\
\text { kisutch) }\end{array}$ & $\begin{array}{l}\text { Blackspot disease/ } \\
\text { trematode larvae } \\
\text { (metacercariae) }\end{array}$ & $\begin{array}{l}\text { Virulence is directly } \\
\text { correlated with daily } \\
\text { maximum temperature }\end{array}$ & $\begin{array}{l}\text { Cairns et al., } \\
2005\end{array}$ \\
\hline $\begin{array}{l}\text { A variety of reef } \\
\text { fish }\end{array}$ & $\begin{array}{l}\text { Ciguatera fish } \\
\text { poisoning (CFP) caused } \\
\text { by bioaccumulation of } \\
\text { algal toxins }\end{array}$ & $\begin{array}{l}\text { Increased incidence of } \\
\text { CFP due to increased } \\
\text { temperature }\end{array}$ & $\begin{array}{l}\text { Tester et al., } \\
2010\end{array}$ \\
\hline $\begin{array}{l}\text { Rainbow trout, } \\
\text { Oncorhynchus } \\
\text { mykiss }\end{array}$ & $\begin{array}{l}\text { Infected with } \\
\text { Ichthyophonus sp. }\end{array}$ & $\begin{array}{l}\text { More rapid onset of } \\
\text { disease, higher parasite } \\
\text { load, more severe host } \\
\text { tissue reaction and } \\
\text { reduced mean-day-to- } \\
\text { death at higher } \\
\text { temperature }\end{array}$ & $\begin{array}{l}\text { Kocan et al., } \\
2009\end{array}$ \\
\hline $\begin{array}{l}\text { Freshwater } \\
\text { bryozoans } \\
\text { infected with } \\
\text { myxozoan, } \\
\text { Tetracapsuloides } \\
\text { bryosalmonae }\end{array}$ & $\begin{array}{l}\text { Spores released from } \\
\text { sacs produced by the } \\
\text { parasite during } \\
\text { infection of freshwater } \\
\text { bryozoans are infective } \\
\text { to salmonid fish, } \\
\text { causing the devastating } \\
\text { Proliferative Kidney } \\
\text { Disease (PKD) }\end{array}$ & $\begin{array}{l}\text { Exacerbate PKD } \\
\text { outbreaks and increase } \\
\text { the geographic range of } \\
\text { PKD as a result of the } \\
\text { combined responses of T. } \\
\text { bryosalmonae and its } \\
\text { bryozoan hosts to higher } \\
\text { temperatures. }\end{array}$ & $\begin{array}{l}\text { Tops et al., } \\
2009\end{array}$ \\
\hline
\end{tabular}

Table 1. Impact of climate change on parasitic and other diseases of aquatic animals.

As the emergence of disease is linked directly to changes in the ecology of hosts or pathogens, or both (Harvell et al., 1999), climate change will have a profound impact on the spread of parasites and disease in aquatic ecosystems (Harvell et al., 1999; Marcogliese, 2001; Harvell et al., 2002). Climate change will affect parasite species directly resulting from the extension of the geographical range of pathogens (Harvell et al., 2002). In addition, 
increased temperature may cause thermal stress in aquatic animals, leading to reduced growth, sub- optimal behaviors and reduced immunocompetence (Harvell et al., 1999; Harvell et al., 2002; Roessig et al., 2004) resulting in changes in the distribution and abundance of their hosts (Marcogliese, 2001). In the oceans, diseases are shown to increase in corals, sea urchins, molluscs, sea turtles and marine mammals, although not all can be linked unequivocally to climate alone (Lafferty et al., 2004). However, it was recently suggested that diseases may not increase with climate change, although distributions of parasites and pathogens will undoubtedly shift (Lafferty, 2009). Other factors may dominate over climate in controlling the distribution and abundance of pathogens, including: habitat alteration, invasive species, agricultural practices and human activities.

\begin{tabular}{|l|l|l|}
\hline Effects on parasites & Effects on hosts & Effects on transmission \\
\hline $\begin{array}{l}\text { Faster embryonic } \\
\text { development and } \\
\text { hatching }\end{array}$ & Altered feeding & Earlier reproduction in spring \\
\hline $\begin{array}{l}\text { Faster rates of } \\
\text { development and } \\
\text { maturation }\end{array}$ & Altered behavior & More generations per year \\
\hline $\begin{array}{l}\text { Decreased longevity of } \\
\text { larvae and adults }\end{array}$ & Altered range & Prolonged transmission in the fall \\
\hline $\begin{array}{l}\text { Increased mortality of all } \\
\text { stages }\end{array}$ & $\begin{array}{l}\text { Altered ecology } \\
\text { Reduced host } \\
\text { resistance }\end{array}$ & Potential transmission year round \\
\hline
\end{tabular}

Table 2. General effects of increased temperature on parasite life cycles, their hosts and transmission processes (Marcogliese, 2008)

Outbreaks of numerous water- borne diseases in both humans and aquatic organisms are linked to climatic events, although it is often difficult to disentangle climatic from other anthropogenic effects. In some cases, these outbreaks occur in foundation or keystone species, with consequences throughout whole ecosystems. There is much evidence to suggest that parasite and disease transmission, and possibly virulence, will increase with global warming. However, the effects of climate change will be superimposed on a multitude of other anthropogenic environmental changes. Climate change itself may exacerbate these anthropogenic effects. Moreover, parasitism and disease may act synergistically with these anthropogenic stressors to further increase the detrimental effects of global warming on animal and human populations, with debilitating social economic ramifications (Marcogliese, 2008).

The repercussions of climate change are not limited solely to temperature effects on hosts and their parasites, but also have other possible effects such as: alteration in water levels and flow regimes, eutrophication, stratification, changes in acidification, reduced ice cover, changes in ocean currents, increased ultra- violet (UV) light penetration, run off, weather extremes (Cochrane et al., 2009). 


\section{Anticipated impacts in next few decades}

In addition to incremental changes of existing trends, complex social and ecological systems such as coastal zones and fisheries, may exhibit sudden qualitative shifts in behaviour when forcing variables past certain thresholds (Daw et al., 2009). For example, IPCC originally estimated that the Greenland ice sheet would take more than 1000 years to melt, but recent observations suggest that the process is already happening faster owing to mechanisms for ice collapse that were not incorporated into the projections (Lenton et al., 2008). The infamous collapse of the Northwest Atlantic northern cod fishery provides a non-climaterelated example where chronic over fishing led to a sudden, unexpected and irreversible loss in production from this fishery. Thus, existing observations of linear trends cannot be used to reliably predict impacts within the next 50 years (Daw et al., 2009).

A study by Veron et al. (2009) also emphasizes impact of increasing atmospheric $\mathrm{CO}_{2}$ levels due to global warming on mass coral bleaching world-wide. According to this group, temperature-induced mass coral bleaching causing mortality on a wide geographic scale started when atmospheric $\mathrm{CO}_{2}$ levels exceeded approximately $320 \mathrm{ppm}$. At today's level of approximately $387 \mathrm{ppm}$, allowing a lag-time of 10 years for sea temperatures to respond, most reefs world-wide are committed to an irreversible decline. Mass bleaching will in future become annual, departing from the 4 to 7 years return-time of El Niño events. Bleaching will be exacerbated by the effects of degraded water-quality and increased severe weather events. In addition, the progressive onset of ocean acidification will cause reduction of coral growth and retardation of the growth of high magnesium calcite-secreting coralline algae. If $\mathrm{CO}_{2}$ levels are allowed to reach $450 \mathrm{ppm}$ (due to occur by 2030-2040 at the current rates), reefs will be in rapid and terminal decline world-wide from multiple synergies arising from mass bleaching, ocean acidification, and other environmental impacts. Damage to shallow reef communities will become extensive with consequent reduction of biodiversity followed by extinctions. Reefs will cease to be large-scale nursery grounds for fish and will cease to have most of their current value to humanity. There will be knock-on effects to ecosystems associated with reefs, and to other pelagic and benthic ecosystems. This is likely to have been the path of great mass extinctions of the past, adding to the case that anthropogenic $\mathrm{CO}_{2}$ emissions could trigger the Earth's sixth mass extinction (Veron et al., 2009).

\section{Climate change impacts on inland fisheries - the Indian scenario}

In recent years the climate is showing perceptible changes in the Indian subcontinent, where the average temperature is on the rise over the last few decades. In India, observed changes include an increase in air temperature, regional monsoon variation, frequent droughts and regional increase in severe storm incidences in coastal states and Himalayan glacier recession (Vass et al., 2009). In some states like West Bengal, the average minimum and maximum temperatures has increased in the range of $0.1-0.9^{\circ} \mathrm{C}$ throughout the state. The average rainfall has decreased and monsoon is also delayed; consequently, the climate change impact is being felt on the temperature of the inland water bodies and on the breeding behavior of fishes. It is well known that temperature is an important factor which strongly influence the reproductive cycle in fishes. Temperature, along with rainfall and photoperiod, stimulate the endocrine glands of fishes which help in the maturation of the gonads. In India, the inland aquaculture is centered on the Indian major carps, Catla catla, 
Labeo rohita and Cirrhinus mrigala and their spawning occurs during the monsoon (June-July) and extend till September. In recent years the phenomenon of IMC maturing and spawning as early as March is observed, making it possible to breed them twice a year. Thus, there is an extended breeding activity as compared to a couple of decades ago (Dey et al., 2007), which appears to be a positive impact of the climate change regime.

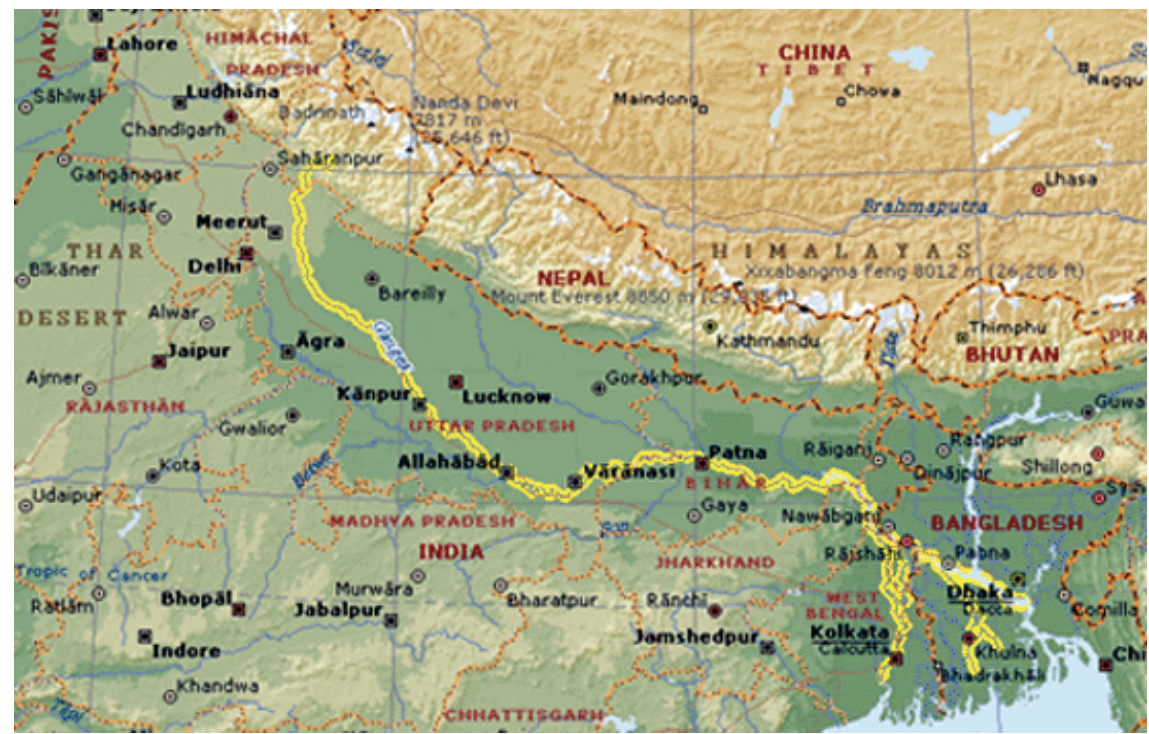

Fig. 1. Course of the River Ganga showing different stretches (http://www.gits4u.com/ water/ganga1.gif)

The mighty river Ganga forms the largest river system in India and not only millions of people depend on its water but it provides livelihood to a large group of fishermen also. The entire length of the river, with a span of $2,525 \mathrm{~km}$ from source to mouth is divided into three main stretches consisting of upper (Tehri to Kanauji), middle (Kanpur to Patna) and lower (Sultanpur to Katwa) (Figure 1). From analysis of 30 years' time series data on river Ganga and water bodies in the plains, Vass et al. (2009) reported an increase in annual mean minimum water temperature in the upper cold-water stretch of the river (Haridwar) by 1.5 ${ }^{\circ} \mathrm{C}$ (from $13{ }^{\circ} \mathrm{C}$ during $1970-86$ to $14.5{ }^{\circ} \mathrm{C}$ during $1987-2003$ ) and by $0.2-1.6{ }^{\circ} \mathrm{C}$ in the aquaculture farms in the lower stretches in the Gangetic plains. This change in temperature clime has resulted in a perceptible biogeographically distribution of the Gangetic fish fauna. A number of fish species which were never reported in the upper stretch of the river and were predominantly available in the lower and middle stretches in the 1950s (Menon, 1954) have now been recorded from the upper cold-water region. Among them, Mastocembelus armatus has been reported to be available at Tehri-Rishikesh and Glossogobius gurius is available in the Haridwar stretch (Sinha et al., 1998) and Xenentodon cancila has also been reported in the cold-water stretch (Vass et al., 2009). The predator-prey ratio in the middle stretch of the river has been reported to be declined from 1:4.2 to 1:1.4 in the last three decades. Fish production has been shown to have a distinct change in the last two decades 
where the contribution from IMCs has decreased from $41.4 \%$ to $8.3 \%$ and that from catfishes and miscellaneous species increased (Vass et al., 2009).

\section{Adaptation and mitigation options}

Adaptation to climate change is defined in the climate change literature as an adjustment in ecological, social or economic systems, in response to observed or expected changes in climatic stimuli and their effects and impacts in order to alleviate adverse impacts of change, or take advantage of new opportunities. Adaptation is an active set of strategies and actions taken by peoples in response to, or in anticipation to the change in order to enhance or maintain their well being. Hence adaptation is a continuous stream of activities, actions, decisions and attitudes that informs decisions about all aspects of life and that reflects existing social norms and processes (Daw et al., 2009).

Many capture fisheries and their supporting ecosystems have been poorly managed, and the economic losses due to overfishing, pollution and habitat loss are estimated to exceed \$50 billion per year (World Bank \& FAO, 2008). The capacity to adapt to climate change is determined partly by material resources and also by networks, technologies and appropriate governance structures. Improved governance, innovative technologies and more responsible practices can generate increased and sustainable benefits from fisheries.

There is a wide range of potential adaptation options for fisheries. To build resilience to the effects of climate change and derive sustainable benefits, fisheries and aquaculture managers need to adopt and adhere to best practices such as those described in the FAO 'Code of Conduct for Responsible Fisheries', reducing overfishing and rebuilding fish stocks. These practices need to be integrated more effectively with the management of river basins, watersheds and coastal zones. Fisheries and aquaculture need to be blended into National Climate Change Adaptation Strategies. In absence of careful planning, aquatic ecosystems, fisheries and aquaculture can potentially suffer as a result of adaptation measures applied by other sectors such as increased use of dams and hydro power in catchments with high rainfall, or the construction of artificial coastal defenses or marine wind farms (ftp://ftp.fao.org/FI/brochure/climate_change/policy_brief.pdf).

Mitigation solutions reducing the carbon footprint of Fisheries and Aquaculture will require innovative approaches. One example is the recent inclusion of Mangrove conservation as eligible for reducing emissions from deforestation and forest degradation in developing countries, which demonstrates the potential for catchment forest protection. Other approaches to explore include finding innovative but environmentally safe ways to sequester carbon in aquatic ecosystems, and developing low-carbon aquaculture production systems (ftp://ftp.fao.org/FI/brochure/climate_change/policy_brief.pdf).

There is mounting interest in exploiting the importance of herbivorous fishes as a tool to help ecosystems recover from climate change impacts. Aquaculture of herbivorous species can provide nutritious food with a small carbon footprint. This approach might be particularly suitable for recovery of coral reefs, which are acutely threatened by climate change. Surveys of ten sites inside and outside a Bahamian marine reserve over a 2.5-year period demonstrated that increases in coral cover, including adjustments for the initial sizedistribution of corals, were significantly higher at reserve sites than those in non-reserve sites: macroalgal cover was significantly negatively correlated with the change in total coral cover over time. Reducing herbivore exploitation as part of an ecosystem-based 
management strategy for coral reefs appears to be justified (Mumby and Harborne, 2010). Furthermore, farming of shellfish, such as oysters and mussels, is not only good business, but also helps clean coastal water, while culturing aquatic plants help to remove waste from polluted water. In contrast to the potential declines in agricultural yields in many areas of the world, climate change opens new opportunities for aquaculture as increasing numbers of species are cultured (ftp://ftp.fao.org/FI/brochure/climate_change/policy_brief.pdf).

Marine fish is one of the most important sources of animal protein for human use, especially in developing countries with coastlines. Marine fishery is also an important industry in many countries. The depletion of fishery resources is happening mainly due to anthropogenic factors such as overfishing, habitat destruction, pollution, invasive species introduction, and climate change. The most effective ways to reverse this downward trend and restore fishery resources are to promote fishery conservation, establish marineprotected areas, adopt ecosystem-based management, and implement a "precautionary principle." Additionally, enhancing public awareness of marine conservation, which includes eco-labeling, fishery ban or enclosure, slow fishing, and MPA (marine protected areas) enforcement is important and effective (Shao, 2009).

The assessment report of the 4th International Panel on Climate Change confirms that global warming is strongly affecting biological systems and that $20-30 \%$ of species risk extinction from projected future increases in temperature. One of the widespread management strategies taken to conserve individual species and their constituent populations against climate-mediated declines has been the release of captive bred animals to wild in order to augment wild populations for many species. Using a regression model based on a 37-year study of wild and sea ranched Atlantic salmon (Salmo salar) spawning together in the wild, McGinnity et al. (2009) showed that the escape of captive bred animals into the wild can substantially depress recruitment and more specifically disrupt the capacity of natural populations to adapt to higher winter water temperatures associated with climate variability, thus increasing the risk of extinction for the studied population within 20 generations. According to them, positive outcomes to climate change are possible if captive bred animals are prevented from breeding in the wild. Rather than imposing an additional genetic load on wild populations by releasing maladapted captive bred animals, they propose that conservation efforts should focus on optimizing conditions for adaptation to occur by reducing exploitation and protecting critical habitats.

\section{Monitoring stress in aquatic animals and HSP70 as a possible monitoring tool}

Temperature above the normal optimum are sensed as heat stress by all organisms, Heat stress (HS) disturbs cellular homeostasis and can lead to severe retardation in growth and development and even death. Heat shock (stress) proteins (HSP) are a class of functionally related proteins whose expression is increased when cells are exposed to elevated temperatures or other stress. The dramatic up regulation of the HSPs is a key part of heat shock (stress) response (HSR). The accumulation of HSPs under the control of heat shock (stress) transcription factors (HSFs) play a central role in the heat stress response (HSR) and acquired thermo tolerance. HSPs are highly conserved and ubiquitous and occur in all organisms from bacteria to yeast to humans. Cells from virtually all organisms respond to different stress by rapidly synthesizing the HSPs and therefore, HSPs are widely used as 
biomarkers for stress response (Jolly and Marimoto, 2000). HSPs have multiple housekeeping functions, such as activation of specific regulatory proteins and folding and translocation of newly synthesized proteins. HSPs are usually produced in large amounts (induction) in response to distinct stressors such as ischemia, hypoxia, chemical/toxic insult, heavy metals, oxidative stress, inflammation and altered temperature or heat shock (Marimoto, 1998).

Out of different HSPs, the HSP70 is unique in many ways; it acts as molecular chaperone in both unstressed and stressed cells. HSC70, the constitutive HSP70 is crucial for the chaperoning functions of unstressed cells, where as the inducible HSP70 is important for allowing cells to cope with acute stress, especially those affecting the protein machinery. HSP70 in marine mussels are widely used as a potential biomarker for stress response and aquatic environmental monitoring of the marine ecosystem (Li et al., 2000).

The success of any organism depends not only on niche adaptation but also the ability to survive environmental perturbation from homeostasis, a situation generally described as stress (Clark et al., 2008a). Although species-specific mechanisms to combat stress have been described, the production of heat shock proteins (HSPs), such as HSP70, is universally described across all taxa. We have studied expression profile of the HSP70 proteins, in different tissues of the large riverine catfish Sperata seenghala (Mohanty et al., 2008), freshwater catfish Rita rita (Mohanty et al., 2010b), Indian catfish Clarias batrachus, Indian major carps Labeo rohita, Catla catla, Cirrhinus mrigala, exotic carp Cyprinus carpio var. communis and the murrel Channa striatus, the climbing perch Anabas testudineus (CIFRI, 2009; Mohanty et al., 2009). Out of these, the IMCs are the major aquaculture species and therefore are of much economic significance. Similarly, Anabas and Channa fetch good market value and their demand is increasing owing to their perceived therapeutic value (Mohanty et al., 2010a). The large riverine catfish $S$. seenghala comprises the major fisheries in majority of rivers and reservoirs and the freshwater catfish Rita rita has a good market demand and these two comprise a major share of the capture fisheries in India.

Monoclonal anti-HSP70 antibody (H5147, Sigma), developed in mouse against purified bovine brain HSP70, in immunoblotting localizes both the constitutive (HSP73) and inducible (HSP72) forms of HSP70. The antibody recognizes brain HSP70 of bovine, human, rat, rabbit, chicken, and guinea pig. We observed immunoreactivity of this antibody with HSP70 proteins in different organs and tissues of a variety of fish species (Table 3). The strong immunoreactivity indicates that the HSP70 proteins of bovine and this riverine catfish Rita rita share strong homology although fish belong to a clade phylogenetically distant from the bovines. Persistent, high level of expression of HSP70 was observed in muscle tissues of Rita rita and for this reason, we have used and recommend use of white muscle tissue of Rita rita as a suitable positive control in analysis of HSP70 expression in tissues of other organisms (Mohanty et al., 2010b).

Early studies on heat shock response in Antarctic marine ectoderms had led to the conclusion that both microorganisms and fish lack the classical heat shock response, i.e. there is no increase in HSP70 expression when warmed (Carratti et al., 1998; Hofmann et al., 2000). However, later it was reported that other Antarctic animals, show an inducible heat shock response, at a level probably set during their temperate evolutionary past (Clark et al., 2008 a, b); the bivalve (clam) Laternula elliptica and gastropod (limpet) Nacella concinna show an inducible heat shock response at $8{ }^{\circ} \mathrm{C}$ and $15^{\circ} \mathrm{C}$, respectively and these are temperatures in excess of that which is currently experienced by these animals, which can be attributed to 
the global warming (Waller et al., 2006). Permanent expression of the inducible HSP70 genes, species-specific high expression of HSC70 ( $N$. concinna) and permanent expression of GRP78 ( $N$ concinna and L. elliptica) indicates that, as for fish, chaperone proteins form an essential part of the adaptation of the biochemical machinery of these animals to low but stable temperatures. High constitutive levels of HSP gene family member expression may be a compensatory mechanism for coping with elevated protein damage at low temperature analogous to the permanent expression of HSP70 in the Antarctic notothenoids (Clark et al., 2008 a). Such studies clearly indicate that both genetics and environment play important role in spatio-temporal gene expression.

\begin{tabular}{|l|l|l|l|l|l|}
\hline Fish species & Liver & Muscle & Kidney & Gill & Remarks \\
\hline Labeo rohita & - & ++ & ++ & ++ & Mohanty et al. 2009 \\
\hline Cirrhinus mrigala & ++ & - & - & ++ & $\begin{array}{l}\text { CIFRI 2009; } \\
\text { Mohanty et al. 2009 }\end{array}$ \\
\hline Cyprinous carpio var communis & ++ & ++ & ++ & - & - do- \\
\hline Anabas testudineus & ++ & - & - & ++ & - do- \\
\hline Channa punctatus & - & - & ++ & & - do- \\
\hline Sperrata seenghala & ++ & ++ & ++ & + & Mohanty et al. 2008 \\
\hline Rita rita & ++ & ++ & ++ & + & Mohanty et al. 2010b \\
\hline
\end{tabular}

Table 3. HSP70 expression profile in different tissues of some freshwater fishes, both aquacultured and wild stock.

There is need to standardize tools suitable for monitoring stress resulting from global warming and climate change impacts, in the aquatic animals from both aqua culture and capture fisheries systems. As HSP70 expression has been reported in many fish species (Table 3) it might serve as a suitable tool for monitoring impact of thermal stress/global warming; however, as HSP70 proteins are expressed under other conditions also, it is necessary to identify the heat shock (stress) transcription factors (HSFs) that can be specifically attributed to global warming (thermal stress) and climate change. It is also necessary to distinguish the constitutive and induced forms of the transcripts/proteins by qPCR/proteomic analysis so that specific HSP70 forms suitable for monitoring performance of the farmed fishes can be monitored for better management of aquacultured animals.

IPCC have predicted an average global warming between +2 and $+6{ }^{\circ} \mathrm{C}$, depending on the scenarios, within the next 90 years (IPCC 2007). The consequences of this increase in temperature are now well documented on both the abundance and geographic distribution of numerous taxa i.e. at population or community levels; in contrast, studies at the cellular level are still scarce. The study of the physiological or metabolic effects of such small increases in temperature is difficult because they are below the amplitude of the daily or seasonal thermal variations occurring in most environments. The underground water organisms are highly thermally buffered and thus are well suited for characterization of cellular responses of global warming. Colson-Proch et al. (2010) studied the genes encoding HSP70 family chaperones in amphipod crustaceans belonging to the ubiquitous subterranean genus Niphargus and HSP 70 sequence in 8 populations of 2 complexes of species of this genus (Niphargus rhenorhodanensis and Niphargus virei complexes). Expression profiles of HSP70 were determined for one of these populations by reverse transcription and quantitative polymerase chain reaction, confirming the inducible nature of this gene. An 
increase of $2{ }^{\circ} \mathrm{C}$ seem to be without any effect on $N$. rhenorhodanensis physiology whereas a heat shock of $+6^{\circ} \mathrm{C}$ represented an important thermal stress for these individuals. Thus this study showed that although Niphargus individuals do not undergo any daily or seasonal thermal variations in underground water, they display an inducible HSP70 heat shock response (Colson-Proch et al., 2010).

\section{Epilogue}

There are opposing viewpoints on the predicted impacts of 'global warming' also. Scientists warn against overselling climate change. Some experts feel that the data produced by models used to project weather changes, risk being over-interpreted by governments, organizations and individuals keen to make plans for a changing climate, with dangerous results. The point made is that the Global Climate Models (GCMs) help us understand pieces of the climate system, but that does not mean we can predict the details. Thus, indications of changes in the earth's future climate must be treated with the utmost seriousness and with the precautionary principle uppermost in our minds. Extensive climate change may alter and threaten the living conditions of much of mankind. They may induce large-scale migration and lead to greater competition for the earth's resources. Such changes will place particularly heavy burdens on the world's most vulnerable countries. There may be increased danger of violent conflicts and wars, within and between states. A wide array of adaptation options is available, but more extensive adaptation than is currently occurring is required to reduce vulnerability to climate change.

Although the understanding of climate change has advanced significantly during the past few decades, many questions remain unanswered. The task of mitigating and adapting to the impacts of climate change will require worldwide collaborative input from a wide range of experts from various fields. The common man's contribution will play a major role in reducing the impacts of climate change and protecting the earth from climate change-related hazards. The impacts of climate change to freshwater aquaculture in tropical and subtropical region is difficult to predict as marine and freshwater populations are affected by synergistic effects of multiple climate and noncelibate stressors. If such noncelibate factors are identified and understood then it may be possible for local predictions of climate change impacts to be made with high confidence (De Silva and Soto, 2009).

Coastal communities, fishers and fish farmers are profoundly affected by climate change. Climate change is modifying the distribution and productivity of marine and freshwater species and is already affecting biological processes and altering food webs, thus making the consequences for sustainability of aquatic ecosystems for fisheries and aquaculture, and for the people dependent on them, uncertain. Fisheries, aquaculture and fish habitats are at risk. Deltas and estuaries are in the fore front and thus, most vulnerable to climate change. Mitigation measures are urgently needed to neutralize and alleviate these growing threats, to adapt to their impacts and also to build our knowledge base on Complex Ocean and aquatic processes. The prime need is to reduce the global emissions of GHGs, which is the primary anthropogenic factor responsible for climate change (ProAct Network, 2008).

Healthy aquatic ecosystems contribute greatly to food security and livelihoods. They are critical for production of wild fish and for some of the seed and much of the feed (trash fish) for aquaculture. Coastal ecosystems provide food, habitats and nursery grounds for fish. Estuaries, coral reefs, mangroves and sea grass beds are particularly important. Mangroves 
create barriers to destructive waves from storms and hold sediments in place with their extensive root systems thereby reducing coastal erosion. Healthy coral reefs, sea grass beds and wetlands provide similar benefits. Thus, these natural systems not only support fisheries, but help protect communities from the terrible impacts of natural hazards and disasters also (ProAct Network, 2008). In freshwater systems, ecosystem health and productivity is linked to water quality and flow and the health of wetlands. Ecosystem-based approaches to fisheries and coastal zone management are highly beneficial as such approaches recognize the need for people to use the ecosystem for their food security and livelihoods while enabling these valuable natural assets to adapt to the effects of climate change, and to reduce the threats from other environmental stresses (Hoegh-Guldberg et al., 2007).

Fish and shellfish provide essential nutrition for 3 billion people and about $50 \%$ of animal protein and micronutrients to 400 million people in the poorest countries of the world. Fish is one of the cheapest sources of animal proteins and play important role in preventing protein-calorie malnutrition. The health benefits of eating fish are being increasingly understood by the consumers. Over 500 million people in the developing countries depend on fisheries and aquaculture for their livelihoods. Aquaculture is the world's fastest growing food production system, growing at $7 \%$ annually. Fish products are among the most widely traded foods internationally (ftp://ftp.fao.org/FI/brochure/climate_change/ policy_brief.pdf).

Implementing adaptation and mitigation pathways for communities dependent on fisheries, aquaculture and aquatic ecosystems will need increased attention from policy-makers and planners. Sustainable and resilient aquatic ecosystems will benefit the fishers as well as the coastal communities and will provide good and services at national and global levels. Fisheries and aquaculture need specific adaptation and mitigation measures like: improving the management of fisheries and aquaculture as well as the integrity and resilience of aquatic ecosystems; responding to the opportunities for and threats to food and livelihood security due to climate change impacts; and helping the fisheries and aquaculture sector reduce GHG emissions. To conclude, the present generation is already facing the harmful effects of the climate change; however, the future generations will suffer most of the harmful effects of global climate change. So, the present generation need to decide, whether to aggressively reduce the chances of future harm at the cost of sacrificing some luxuries or to let our descendants largely fend for themselves (Broome, 2008). Thus, how we handle the issue of Climate Change is more of an ethical question and the global community must act sensibly and responsibly.

\section{References}

Barange, M., \& Perry, R.I. (2009) Physical and ecological impacts of climate change relevant to marine and inland capture fisheries and aquaculture In: Climate change implications for fisheries and aquaculture overview of current scientific Knowledge, Cochrane, K., Young, C. De, Soto, D., \& Bahri, T. (Eds). FAO Fisheries and Aquaculture Technical paper: No. 530, pp. 7-106, FAO, Rome.

Battin, J., Wiley, M. W., Ruckelshaus, M. H., Palmer, R. N,. Korb, E., Bartz, K. K., \& Imaki, H. (2007) Projected impacts of climate change on salmon habitat restoration, Proc. Natl. Acad. Sci, USA, 104, 6720-6725. 
Brander, K. M. (2007) Global fish production and climate change, Proc. Natl. Acad. Sci., USA, 104, 19709-19714.

Broome, J. (2008) The ethics of climate change, Sci. Am., 298, 96-100.

Cairns, M. A., Ebersole, J. L., Baker, J. P., Wigngton, P. J. Jr., Lavigne, H. R., \& Davis, S. M. (2005) Influence of summer stream temperatures on black spot infestation of juvenile coho salmon in the Oregon Coast Range, Trans. Am. Fish. Soc., 134, 1471-1479.

Carrattù, L., Gracey, A. Y, B.uono, S., \& Maresca, B. (1998) Do Antarctic fish respond to heat shock? In: Fishes of Antarctica. A Biological Overview. di Prisco, G., Pisano, E., Clarke, A. (Eds) Springer, Italy.

Chassot, E., Bonhommeau, S., Dulvy NK, Mélin F, Watson R, Gascuel D, Le Pape O. (2010) Global marine primary production constrains fisheries catches. Ecol Lett., Feb 5. [Epub ahead of print]

CIFRI (2009) Annual Report. Central Inland Fisheries Research Institute, Barrackpore, Kolkata, India. ISSN 09706267.

Clark, M. S., Fraser, K. P. P., \& Peck, L. S. (2008a) Antarctic marine molluscs do have an HSP70 heat shock response, Cell Stress Chaperon., 13, 39-49.

Clark, M. S., Geissler, P., Waller, C., Fraser, K. P. P., Barnes, D. K. A., \& Peck, L. S. (2008b) Low heat shock thresholds in wild Antarctic inter-tidal limpets (Nacella concinna). Cell Stress Chaperon., 13, 51-58.

Cochrane, K., Young, C. De, Soto, D., \& Bahri, T. (2009) Climate change implications for fisheries and aquaculture: overview of current scientific knowledge. FAO Fisheries and Aquaculture Technical paper: No. 530,FAO, Rome.

Colson-Proch, C., Morales, A., Hervant, F., Konecny, L., Moulin, C., \& Douady, C. J. (2010) First cellular approach of the effects of global warming on groundwater organisms: a study of the HSP70 gene expression. Cell Stress Chaperon., 15, 3, 259-270.

Daufresne, M., Lengfellner, K., \& Sommer, U. (2009) Global warming benefits the small in aquatic ecosystems. Proc Natl Acad Sci USA., 106, 31, 12788-12793.

Daw, T., Adger, W. N., Brown, K., \& Badjeck, M.-C. (2009) Climate change and capture fisheries: potential impacts, adaptation and mitigation. In: Climate change implications for fisheries and aquaculture overview of current scientific Knowledge, Cochrane, K., Young, C. De, Soto, D., \& Bahri, T. (Eds). FAO Fisheries and Aquaculture Technical paper: No. 530, pp.107-150, FAO, Rome.

De Silva, S. S. and Soto, D. 2009, Climate change and aquaculture: potential impacts, adaptation and mitigation In: Climate change implications for fisheries and aquaculture overview of current scientific Knowledge, Cochrane, K., Young, C. De, Soto, D., \& Bahri, T. (Eds). FAO Fisheries and Aquaculture Technical paper: No. 530, pp. 151212, FAO, Rome.

Dey, S., Srivastava, P. K., Maji, S., Das, M. K., Mukhopadhyay, M. K., \& Saha, P. K. (2007) Impact of climate change on the breeding of Indian major carps in West Bengal. J. Inland Fish. Soc. India, 39, 1, 26-34.

Done, T., Whetton, P., Jones, R. et al. (2003) Global climate change and coral bleaching on the Great Barrier Reef. Final report to the State of Queensland Greenhouse taskforce through the Department of Natural Resources and Mines, Queensland,.

Esch, G. W., \& Hazen, T. C. (1980) Stress and body condition in a population of largemouth bass: implications for red-sore disease, Trans. Am. Fish. Soc., 109, 532-536. 
FAO (2005) Increasing the contribution of small-scale fisheries to poverty alleviation and food security. FAO Technical Guidelines for Responsible Fisheries. No. 10, 79 p., FAO, Rome.

FAO (2007) The state of world fisheries and aquaculture - 2006, 162 p., FAO, Rome.

Granath, W. O. Jr., \& Esch, G. W. (1983) Survivorship and parasite- induced host mortality among mosquio fish in a predator- free, North Carolina cooling reservoir, Am. Midland Naturalist, 110, 314-323.

Harvell, C. D., Kim, K., Burkholder, J. M., Colwell, R. R., Epstein, P. R., Grimes, D. J., Hofmann, E. E., Lipp, E. K., \& Osterhaus, A. D. Overstreet RM et al. (1999) Emerging marine diseases- climate links and anthropogenic factors, Science, 285, 1505-1510.

Harvell, C. D., Mitchell, C. E., Ward, J. R., Altizer, S., Dobson, A. P., Ostfeld, R. S \& Samuel, M.D. (2002) Climate warming and disease risks for terrestrial and marine biota, Science, 296, 5576, 2158-2162.

Hiner, M., \& Moffitt, C. M. (2001) Variation in infections of Myxobolus cerebralis in fieldexposed cutthroat and rainbow trout in Idaho, J. aquat. Anim. Hlth, 13, 124-132.

Hoegh-Goldberg, O. et al. (2007) Coral reefs under rapid climate change and ocean acidification. Science, 318, 1737-1742.

Hofmann, G. E., Buckley, B. A., Airaksine, S., Keen, J. E., \& Somero, G. N. (2000) Heat-shock protein expression is absent in the Antarctic fish Trematomus bernacchii family Nototheniidae. J Exp Biol., 203, 2331-2339.

IPCC (2007) Fourth Assessment Report - Climate Change 2007: Synthesis Report, 2007.

IPCC (2001) Climate Change 2001. IPCC Third Assessment Report, 2001.

Jolly, C., \& Marimoto, R. I. (2000) Role of the heat shock response and molecular chaperones in oncogenesis and cell death, J. Natl Cancer Inst. 92, 1564-1572.

Kocan, R., Hershberger, P., Sanders, G., \& Winton, J. (2009) Effects of temperature on disease progression and swimming stamina in Ichthyophonus-infected rainbow trout, Oncorhynchus mykiss (Walbaum), J Fish Dis., 32, 10, 835-43.

Lafferty, K. D. (2009) The ecology of climate change and infectious diseases. Ecology, 90, 888-900.

Lafferty, K. D., Porter, J. W \& Ford, S. E. (2004) Are diseases increasing in the ocean? Ann. Rev. Ecol. Evol. Syst., 35, 31-54.

Lenton, T. M., Held, H., Kriegler, E., Hall, J. W., Lucht, W., Rahmstorf, S., \& Schellnhuber, H. J. (2008) Tipping elements in the earth's climate system, Proc Natl Acad Sci, USA, 105, 6, 1786-1793.

Li, C. Y., Lee, J. S., Ko, Y. G., Kim, J. I. \& Seo, J. S. (2000) Heat shock protein 70 inhibits apoptosis downstream of cytochrome c release and upstream of caspase-3 activation. J. Biol. Chem., 275, 25665-25671.

Ling, S. D., Johnson, C. R., Frusher, S. D., \& Ridgway, K. R. (2009) Overfishing reduces resilience of kelp beds to climate-driven catastrophic phase shift, Proc Natl Acad Sci USA., 106, 52, 22341-22345.

Mantzouni, I., \& Mackenzie, B. R. (2010) Productivity responses of a widespread marine piscivore, Gadus morhua, to oceanic thermal extremes and trends. Proc Biol Sci. Feb 10. [Epub ahead of print].

Marcogliese, D. J. (2008) The impact of climate change on the parasites and infectious diseases of aquatic animals, Rev. sci. tech. Off. int. Epiz., 27, 2, 467-484.

Marimoto, R.J. (1998) Regulation of the heat shock transcriptional response: cross talk between a family of heat shock factors, molecular chaperones and negative regulators. Genes Dev., 12, 3788-3796. 
McGinnity, P., Jennings, E., DeEyto, E., Allott, N., Samuelsson, P., Rogan, G., Whelan, K., \& Cross, T. (2009) Impact of naturally spawning captive-bred Atlantic salmon on wild populations: depressed recruitment and increased risk of climate-mediated extinction, Proc Biol Sci. 276, 1673, 3601-3610.

Menon, A. G. K. (1954) Fish geography of the Himalayas. Zoological Survey of India, Calcutta. 11, 4, 467-493.

Mohanty, B. P., Mondal, K., Bhattacharjee, S., \& Vass, K. K. (2008) HSP 70 expression profile in tissues of the large riverine catfish Aorichthys seenghala (Sykes). P-GNB-58, p.153. $8^{\text {th }}$ Indian Fisheries Forum 22-26 Nov 2008, Kolkata, India; jointly organized by CIFRI, Inland Fisheries Society of India and Indian Fisheries Forum. ISBN-8185482-14-4.

Mohanty, B. P., Bhattacharjee, S, Mondal, K., \& Das, M. K. (2009) HSP 70 expression in different tissues of some important tropical freshwater fishes. $96^{\text {th }}$ Indian Science Congress, 3-7 January 2009, organized by NEHU, Shillong, India.

Mohanty, S., \& Mohanty, B. P. (2009) Global climate change: a cause of concern, Natl Acad Sci Lett, 32, 5 \& 6, 149-156.

Mohanty, B. P., Behera, B. K., \& Sharma, A. P. (2010a) Nutritional significance of small indigenous fishes in human health. Bulletin No. 162, Central Inland Fisheries Research Institute, Barrackpore, Kolkata, India. ISSN 0970-616X.

Mohanty, B. P., Bhattacharjee, S., Mondal, K., \& Das, M. K. (2010b) HSP70 expression profiles in white muscles of riverine catfish Rita rita show promise as biomarker for pollution monitoring in tropical rivers. Natl Acad Sci Lett., 33, 5 \& 6, 177-182.

Mumby, P. J., \& Harborne, A. R. (2010) Marine reserves enhance the recovery of corals on Caribbean reefs, PLoS One 5, 1, e8657.

National Climate Data Centre, National Oceanic and Atmospheric Administration. Global warming: frequently asked questions. Available at: www.ncdc.noaa.gov/oa/ climate/globalwarming.html. Accessed December 9, 2008.

Nicholls, R. J., Wong, P. P., Burkett, V. R., Codignotto, J. O., Hay, J. E., McLean, R. F., Ragoonaden, S., \& Woodroffe, C. D. (2007) Coastal systems and low-lying areas. In: Climate Change 2007: impacts, adaptation and vulnerability, Parry, M. L., Canziani, O. F., Palutikof, J. P., Linden, V. D. \& Hanson, C. E., (Eds.), pp. 315-356. Contribution of working group II to the Fourth Assessment Report of the Intergovernmental Panel on Climate Change, Cambridge University Press, Cambridge, UK.

Orr, J. C., Fabry, V. J., Aumont, O., Bopp, L., Doney, S. C., Feely, R. A., Gnanadesikan, A., Gruber, N., Ishida, A., Joos, F., Key, R. M., Lindsay, K., Maier-Reimer, E., Matear, R., Monfray, P., Mouchet, A., Najjar, R. G., Plattner, G-K, Rodgers, K. B., Sabine, C. L., Sarmiento, J. L., Schlitzer, R., slater, R. D., Totterdell, I. J., Weirig, M-F., Yamanaka, Y., \& Yool, A. (2005) Anthropogenic ocean acidification over the twenty-first century and its impact on calcifying organisms. Nature, 437, 681-686.

ProAct Network (2008) The role of environmental management and eco-engineering in disaster risk reduction and climate change adaptation.

Prowse, T. D., Furgal, C., Wrona, F. J., \& Reist, J. D. (2009) Implications of climate change for northern Canada: freshwater, marine, and terrestrial ecosystems, Ambio, 38, 5, 282-289.

Regional Framework for action to protect human health from effects of climate change in the South East Asia and Pacific Region. 2007. Available at http:/ / www.searo.who.int/ en/Section260/Section2468_14335.htm. Accessed December 9, 2008. 
Scott, M. A., Locke, M., \& Buck, L. T (2003) Tissue- specific expression of inducible and constitutive Hsp70 isoforms in the western painted turtle, J Exptl. Biol., 206, 303-311.

Shao, K. T. (2009) Marine biodiversity and fishery sustainability. Asia Pac J Clin Nutr., 18, 4, 527-531.

Shea, K. M., \& the Committee on Environmental Health. (2007) Global Climate Change and children's health. Pediatrics, 120, e1359-e1367.

Sinha, M., De, D. K., \& Jha, B. C. (1998) The Ganga- Environment and Fishery. Central Inland Fisheries Research Institute, Barrackpore, Kolkata, India.

Tester, P. A., Feldman, R. L., Nau, A. W., Kibler, S. R., \& Wayne Litaker, R. (2010) Ciguatera fish poisoning and sea surface temperatures in the Caribbean Sea and the West Indies. Toxicon. Mar 3. [Epub ahead of print]

Thorpe, A., Reid, C., Anrooy, R. V., Brugere, C., \& Becker, D. (2006) Poverty reduction strategy papers and the fisheries sector: an opportunity forgone?, J Intl. Dev., 18, 4, 487-517.

Tops, S., Hartikainen, H. L., \& Okamura, B. (2009) The effects of infection by Tetracapsuloides bryosalmonae (Myxozoa) and temperature on Fredericella sultana (Bryozoa). Int J Parasitol., 39, 9, 1003-1010.

Understanding and responding to Climate Change. 2008 Edn. pp. 1-24. The National Academies, USA (http://www.national-academies.org)

Vass, K. K., Das, M. K., Srivastava, P. K. \& Dey, S. (2009) Assessing the impact of climate change on inland fisheries in River Ganga and its plains in India. Aqu Ecosys Health E Management., 12, 2, 138-151.

Veron, J. E., Hoegh-Guldberg, O., Lenton, T. M., Lough, J. M., Obura, D. O., Pearce-Kelly, P., Sheppard, C. R., Spalding, M., Stafford-Smith, M. G., \& Rogers, A. D. (2009) The coral reef crisis: the critical importance of $<350$ ppm CO2. Mar Pollut Bull., 58, 10, 1428-1436.

Waller, C., Barnes, D. K. A., \& Convey, P. (2006) Ecological contrasts across an Atlantic landsea interface, Austral Ecol, 31, 656-666.

Walther, G. R., Roques, A., Hulme, P. E., Sykes, M. T., Pysek, P., Kühn, I., Zobel, M., Bacher, S., Botta-Dukát, Z., Bugmann, H., Czúcz, B., Dauber, J., Hickler, T., Jarosík, V., Kenis, M., Klotz, S., Minchin, D., Moora, M., Nentwig, W., Ott, J., Panov, V. E., Reineking, B., Robinet, C., Semenchenko, V., Solarz, W., Thuiller, W., Vilà, M., Vohland, K., \& Settele, J. (2009) Alien species in a warmer world: risks and opportunities. Trends Ecol Evol., 24, 12, 686-693.

WMO World Data Centre for Greenhouse Gases. Greenhouse gas bulletin: the state of greenhouse gases in the atmosphere using global observations up to December 2004. Vol.1, March 14, 2006.

World Bank \& FAO (2008) The sunken billions: the economic justification for fisheries reform. Agriculture and Rural Development Dept. The World Bank: Washington DC. www.worldbank.org.sunkenbillions 


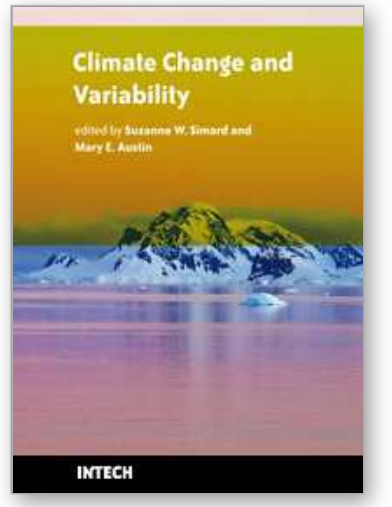

\author{
Climate Change and Variability \\ Edited by Suzanne Simard
}

ISBN 978-953-307-144-2

Hard cover, 486 pages

Publisher Sciyo

Published online 17, August, 2010

Published in print edition August, 2010

Climate change is emerging as one of the most important issues of our time, with the potential to cause profound cascading effects on ecosystems and society. However, these effects are poorly understood and our projections for climate change trends and effects have thus far proven to be inaccurate. In this collection of 24 chapters, we present a cross-section of some of the most challenging issues related to oceans, lakes, forests, and agricultural systems under a changing climate. The authors present evidence for changes and variability in climatic and atmospheric conditions, investigate some the impacts that climate change is having on the Earth's ecological and social systems, and provide novel ideas, advances and applications for mitigation and adaptation of our socio-ecological systems to climate change. Difficult questions are asked. What have been some of the impacts of climate change on our natural and managed ecosystems? How do we manage for resilient socio-ecological systems? How do we predict the future? What are relevant climatic change and management scenarios? How can we shape management regimes to increase our adaptive capacity to climate change? These themes are visited across broad spatial and temporal scales, touch on important and relevant ecological patterns and processes, and represent broad geographic regions, from the tropics, to temperate and boreal regions, to the Arctic.

\title{
How to reference
}

In order to correctly reference this scholarly work, feel free to copy and paste the following:

Bimal Mohanty, Sasmita Mohanty, Jnanendra Sahoo and Anil Sharma (2010). Climate Change: Impacts on Fisheries and Aquaculture, Climate Change and Variability, Suzanne Simard (Ed.), ISBN: 978-953-307-144-2, InTech, Available from: http://www.intechopen.com/books/climate-change-and-variability/climate-changeimpacts-on-fisheries-and-aquaculture

\section{INTECH}

open science | open minds

\author{
InTech Europe \\ University Campus STeP Ri \\ Slavka Krautzeka 83/A \\ 51000 Rijeka, Croatia \\ Phone: +385 (51) 770447 \\ Fax: +385 (51) 686166 \\ www.intechopen.com
}

\author{
InTech China \\ Unit 405, Office Block, Hotel Equatorial Shanghai \\ No.65, Yan An Road (West), Shanghai, 200040, China \\ 中国上海市延安西路65号上海国际贵都大饭店办公楼 405 单元 \\ Phone: +86-21-62489820 \\ Fax: +86-21-62489821
}


(C) 2010 The Author(s). Licensee IntechOpen. This chapter is distributed under the terms of the Creative Commons Attribution-NonCommercialShareAlike-3.0 License, which permits use, distribution and reproduction for non-commercial purposes, provided the original is properly cited and derivative works building on this content are distributed under the same license. 